\title{
Evaluation of the internal thoracic artery blood flow before and after Nuss operation: is it reversible?
}

\author{
Nuss ameliyatı öncesi ve sonrası internal torasik arter akımının değerlendirilmesi: geri \\ dönüşümlü müdür?
}

\author{
Pınar KURU-BEKTAŞOĞLU, Nezih Onur ERMERAK, Canan CIMSSít, Çağatay ÇETINNKAYA, Hıncal ÖZBAKIR, \\ Nural BEKİROĞLU, Tunç LAÇİN, Mustafa YÜKSEL
}

\begin{abstract}
Objective: Obstruction of the internal thoracic arteries (ITAs) by the Nuss bars in minimally invasive repair of pectus excavatum (MIRPE) has been documented in the literature. In this study, we aim to investigate the patency of ITAs before and after repair of the pectus excavatum with the Nuss procedure, by using color Doppler ultrasonography (US).

Materials and Methods: Nineteen patients who underwent Nuss procedure were included in this study prospectively. Color Doppler US examinations were performed for comparing ITA patency after insertion of the Nuss bars and after their removal. Patients were evaluated according to gender, age, symmetry of deformity, Haller index, and the number of Nuss bars inserted.

Results: Nineteen patients operated with MIRPE (17 male and 2 females with a mean age $21.78 \pm 6.35$ ) were enrolled in the study. Eight patients (42.1\%) with normal ITA blood flow preoperatively had normal blood flow after removal of the bar. In preoperative examination, 6 patients had bilateral $(n=2)$ or unilateral $(n=4)$ obstruction of the ITA and 5 patients had bilateral $(n=2)$ or unilateral $(\mathrm{n}=3)$ abnormally disturbed flow. After the bar removal only $2(10 \%)$ of the affected patients $(57.9 \%)$ still had obstruction whereas patent blood flow of the ITAs has been noted in 9 patients.

Conclusion: We have shown that after the Nuss bar removal, only $10 \%$ of the ITAs are compromised.
\end{abstract}

Keywords: Pectus excavatum, Chest wall deformities, Internal thoracic arteries, Minimally invasive repair of pectus excavatum, Doppler ultrasonography

Pınar Kuru-Bektaşoğlu (四)

Department of Neurosurgery, Fatih Sultan Mehmet Education and Research Hospital, University of Health Sciences, Istanbul, Turkey and

Department of Physiology, School of Medicine, Marmara University, Istanbul, Turkey

e-mail:pnr.kuru@gmail.com

Nezih Onur Ermerak, Çağatay Çetinkaya, Tunç Laçin, Mustafa Yüksel Department of Thoracic Surgery, School of Medicine, Marmara University, Istanbul, Turkey

Canan Cimşit

Department of Radiology, School of Medicine, Marmara University, Istanbul, Turkey

Hıncal Özbakır

School of Medicine, Marmara University, Istanbul, Turkey

Nural Bekiroğlu

Department of Biostatistics, School of Medicine, Marmara University Istanbul, Turkey
Öz

Amaç: Pektus ekskavatumun, Nuss barları ile minimal invaziv onarımında internal torasik arter (ITA) tıkanması literatürde bildirilmiştir. $\mathrm{Bu}$ çalışmada, ITA tıkanıklığının, Nuss bar takılmasından ve çıkarılmasından sonraki durumununun renkli Doppler ultrasonografi ile değerlendirilmesi amaçlanmıştır.

Gereçler ve Yöntemler: Nuss bar operasyonu uygulanan 19 hasta çalışmaya prospektif olarak dahil edilmiştir. Renkli Doppler ultrasonografi ile Nuss bar takıldıktan sonra ve Nuss bar çıkartıldıktan sonra ITA akımı karşılaştırılmıştır. Hastalar cinsiyet, yaş, deformitenin simetrisi, Haller indeksi ve takılan bar sayısı açısından değerlendirilmiştir.

Bulgular: Nuss bar operasyonu uygulanan 19 pektus ekskavatumlu hasta (17 erkek, 2 kadın, ortalama yaş: 21,78 \pm 6.35 ) çalışmaya alındı. Sekiz hastanın $(\% 42,1)$ bar çekimi öncesi ve sonrası ITA akımı normal olarak değerlendirildi. Bar çekimi öncesi muayenede 6 hastada çift taraflı $(n=2)$, ya da tek taraflı $(n=4)$ ITA tıkanıklığı, ve 5 hastada çift taraflı $(\mathrm{n}=2)$, ya da tek taraflı $(\mathrm{n}=3)$ ITA akım bozukluğu tespit edildi. Bar çekildikten sonra etkilenen hastalardan $(\% 57,9)$ sadece 2 hastada $(\% 10)$ tıkanma devam etmekteydi. Dokuz hastada ITA kan akımı normal olarak değerlendirildi.

Sonuç: Bar çıkartıldıktan sonra, ITA'lerin sadece \%10'unda etkilenim devam etmekte idi.

Anahtar kelimeler: Pektus ekskavatum, Gögüs duvarı deformiteleri, İnternal torasik arter, Pectus ekskavatumun minimal invaziv onarımı, Doppler ultrasonografi

\section{Introduction}

Pectus excavatum (PE) is characterized by depression of the sternum and costal cartilages (funnel-shaped chest wall) [1]. PE is the most common chest wall deformity which represents the $90 \%$ of all chest wall deformities and it has $0.1-0.8 \%$ incidence $[2,3]$. The classic surgical method for correction of PE is the Ravitch sternochondroplasty [4,5]. Large incisions and scars limit this operation's satisfactory results. For more than 20 years, minimally invasive repair 
of pectus excavatum (MIRPE) has become a widely used technique in the clinical settings $[6,7]$. This technique, which is first described in 1987 by Dr. Donald Nuss, enables thoracic surgeons correcting these deformities with small bilateral incisions for using a retrosternal shaped bar inserted by a thoracoscope [8].

The internal thoracic artery (ITA) is located at medial border of anterior scalene muscle at the root of neck and descends into the thorax posterior to clavicle and first costal cartilage [9]. Nuss bars are likely to compress ITAs and affect the blood flow. This can result with diminished flow or obstruction and could become important if patients require coronary artery bypass grafting $(\mathrm{CABG})$ in later years. Yuksel and his colleagues reported that ITAs are compromised in $44 \%$ of patients after the Nuss procedure [10]. Külcü and his colleagues also reported that ITA patency was affected in $67 \%$ of the patients after removal of the Nuss bars [11]. Multidetector computed tomography (CT) is a widely used, reliable, non-invasive method for evaluation of ITA anatomy, flow and patency [10]. The age of the patient population, the need for frequent imaging in follow up, and hence the side effects of radiation led to the idea of using color Doppler ultrasonography (US) to assess ITA blood flow. This study was performed to investigate the patency of the ITAs on the long term period after Nuss procedure and define the permanency of obstruction in ITAs after the bar removal.

\section{Materials and Methods}

\section{Patients}

This prospective study was performed between January 2014 and November 2014 at Marmara University Hospital with Local Ethics Committee approval and written informed consents of the patients. Nineteen patients (17 male and 2 females with a mean age $21.78 \pm 6.35$ ) operated with Nuss procedure were included in the study. The detailed explanation of surgical technique has been explained elsewhere [1215]. Patients younger than 16 years of age with a history of thoracic surgery, and those with prominent costochondral deformity and angulation preventing adequate ultrasound examination $(n=3)$ were excluded and not listed in the results section. Preoperative evaluation consisted of respiratory function tests, electrocardiography, postero-anterior and lateral chest X-rays and complete blood count. Patients were evaluated according to gender, age, symmetry of deformity, Haller index, and the number of Nuss bars inserted.

\section{Imaging}

Doppler US examinations were performed for documenting ITA patency before and after Nuss bar removal. Color Doppler US examinations were performed using a linear 9-15 MHz multifrequency transducer (Logiq E9, GE Healthcare, Milwaukee, USA) for documenting ITA patency after the insertion of the bar and on the $10^{\text {th }}$ postoperative day. Same radiologist performed all color Doppler US examinations after the procedure and postoperatively. Doppler signals were obtained with supraclavicular approach followed by intercostal approach. ITAs were identified as tubular structures with color flow directed from base to apex. Intraluminal flow signals were obtained using the color Doppler method. The angle of the US beam was corrected for the velocity measurements between 45-60 degrees to ensure that the sampling volume was located within the vessel lumen for as much of the cardiac cycle as possible. Doppler measurements of the arterial lumen diameter, peak systolic velocity, and flow characteristics were recorded proximal and distal to the bar(s) bilaterally.

\section{Patient groups}

According to blood flow characteristics of the ITAs, patients were grouped into two: Patients with normal blood flow characteristics (triphasic or biphasic flow dominant during systole, with low velocities during diastole) before and after bar removal with no change in flow velocity formed the unaffected group (Figure 1). Patients with monophasic low flow rate or monophasic-dampened flow characteristics in Doppler examination of ITA as well as patients where no Doppler signal were seen formed the affected group (Figure 2).

\section{Statistical analysis}

All analyses were performed using Statistical Package for the Social Science Program (SPSS) (IBM Corp. Released 2011. IBM SPSS Statistics for Windows, Version 20.0. Armonk, NY: IBM Corp.). The characteristics of patients were evaluated with descriptive statistics. Comparison of the mean values was performed with paired samples chisquare test and McNemar test. p values lower than 0.05 was accepted as statistically significant. While presenting descriptive statistics, continuous data were presented as mean \pm standard deviation (SD) and categorical data as frequencies and percentages. 


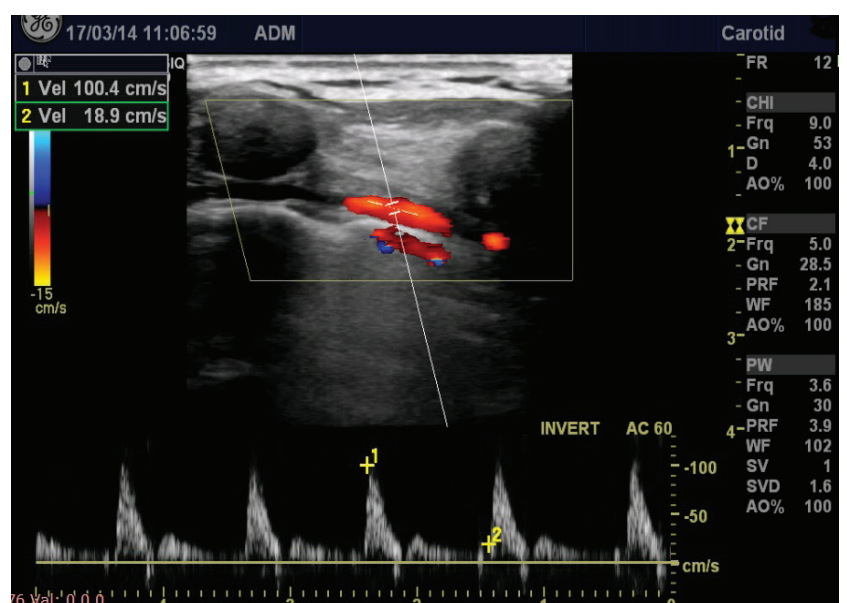

Figure 1: A seventeen-year-old male patient with a single bar insertion showing normal triphasic blood flow characteristics in ITA

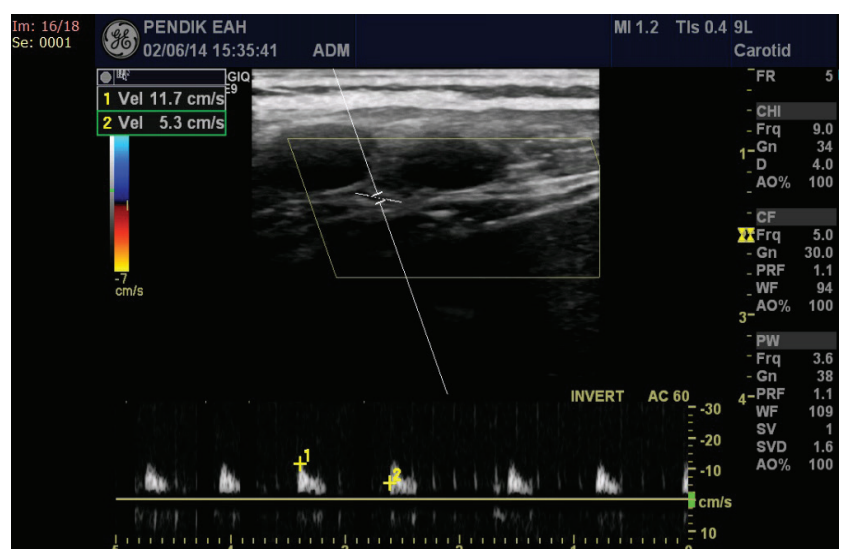

(a)

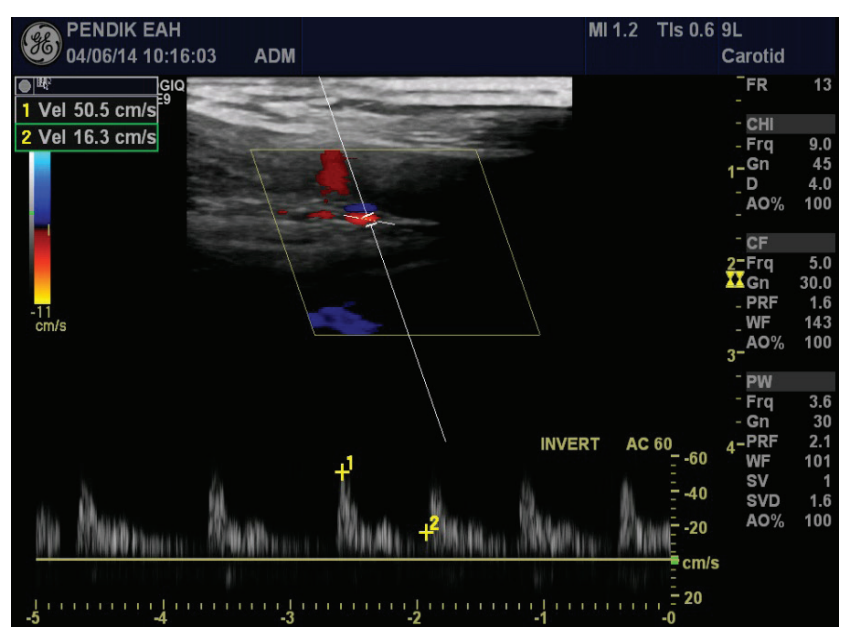

(b)

Figure 2: A sixteen-year-old male patient showing monophasicdampened flow characteristics in ITA before the bar removal (a). Note the change of flow characteristics to biphasic form after the bar removal (b).

\section{Results}

Nineteen patients who had been operated with MIRPE (17 male and 2 females with a mean age 21.78 \pm 6.35 ) were evaluated prospectively. Patient characteristics were summarized in Table I. The Haller index of the patients were $3.86 \pm 1.25$. A single bar was inserted in 12 patients and two bars were required in 7 patients for the correction of the deformity. The mean time interval for the duration of the bar placement was $33.42 \pm 17.51$ months (Range:11-82 months). There was no significant difference between affected and unaffected groups regarding gender, age, symmetry of deformity, Haller index, and the number of Nuss bars inserted $(\mathrm{p}>0.05)$.

Eight patients (42.1\%) with normal ITA blood flow after the insertion of the bars had normal blood flow after the removal of the bars (unaffected patients). ITA flow was affected in 11 patients $(57.9 \%)$ : In the examination performed after the procedure, 6 patients had bilateral $(\mathrm{n}=2)$ or unilateral $(\mathrm{n}=4)$ obstruction of ITA and 5 patients bilaterally $(\mathrm{n}=2)$ or unilaterally $(\mathrm{n}=3)$ had abnormally disturbed flow. After the bar removal only $2(10 \%)$ of the affected patients (57.9\%) still had obstruction findings ( $\mathrm{p}=$ 0.004). Doppler findings were summarized in Table II. The level of intercostal placement of the bars were determined according to deformity area. These two patients had their bars in the $3^{\text {rd }}$ and $4^{\text {th }}$ intercostal spaces (ICS). One of the patients was a 21 year-old female with asymmetric deformity and the other one was a 21 year-old male with symmetric deformity. An increase in the blood flow of the ITAs has been noted in the rest of the affected group $(n=9)$.

\section{Discussion}

Nuss operation is rather a safe and successful method and has several advantages over classic open surgery treatment of PE. However, some complications regarding the Nuss procedure could be seen (i.e. pneumothorax, lung parenchymal laceration, bar displacement) $[12,16-$ 18]. According to recent reviews, the overall complication rate of the Nuss procedure changes between 26-33\% [19, 20]. In the long term, Nuss bars can apply chronic pressure on ITAs because it lifts the sternum and neighboring structures and this can result in obliteration of these arteries [10]. Computed tomography angiography (CTA) showed that blood flow was affected in $44 \%$ and severity ranged from either unilateral or bilateral diminished blood flow or complete obstruction in early postoperative period. It 
Table I. Characteristics of the patients and ITA status before and after the the bar removal

\begin{tabular}{|c|c|c|c|c|c|c|c|c|c|}
\hline $\begin{array}{l}\text { Patient } \\
\text { number }\end{array}$ & Age & $\mathbf{M} / \mathbf{F}$ & Deformity & $\begin{array}{l}\text { Haller } \\
\text { Index }\end{array}$ & $\begin{array}{c}\text { Time } \\
\text { month }\end{array}$ & Bar & ICS & $\begin{array}{l}\text { Bar } \\
\text { size }\end{array}$ & Group \\
\hline 1 & 17 & $\mathrm{M}$ & Symmetric & 2.25 & 30 & 1 & $\mathrm{R}-4^{\text {th }}, \mathrm{L}-3^{\text {rd }}$ & 305 & Unaffected \\
\hline 2 & 26 & M & Symmetric & 3.83 & 25 & 2 & $4^{\text {th }}$ and $5^{\text {th }}$ & $355+330$ & Affected \\
\hline 3 & 23 & $\mathrm{M}$ & Symmetric & 3.36 & 11 & 1 & $4^{\text {th }}$ & 305 & Unaffected \\
\hline 4 & 39 & $\mathrm{M}$ & Asymmetric & 3.14 & 33 & 2 & $3^{\text {rd }}$ and $4^{\text {th }}$ & $288+305$ & Unaffected \\
\hline 5 & 23 & $\mathrm{~F}$ & Asymmetric & 3 & 36 & 2 & $2^{\text {nd }}$ and $4^{\text {th }}$ & $355+355$ & Unaffected \\
\hline 6 & 23 & $\mathrm{M}$ & Asymmetric & 3.33 & 36 & 1 & $\mathrm{R}-4^{\text {th }}, \mathrm{L}-3^{\text {rd }}$ & 305 & Unaffected \\
\hline 7 & 26 & M & Symmetric & 6.8 & 25 & 2 & $\begin{array}{l}\text { 1.R-- } 4^{\text {th }}, \mathrm{L}-3^{\text {rd }} \\
2 . \mathrm{R}-5^{\text {th }}, \mathrm{L}-4^{\text {th }}\end{array}$ & $355+355$ & Affected \\
\hline 8 & 25 & $\mathrm{M}$ & Symmetric & 3.04 & 38 & 1 & $\mathrm{R}-5^{\text {th }}, \mathrm{L}-4^{\text {th }}$ & 355 & Affected \\
\hline 9 & 15 & $\mathrm{M}$ & Symmetric & 6.67 & 25 & 1 & $\mathrm{R}-4^{\text {th }}, \mathrm{L}-5^{\text {th }}$ & 355 & Unaffected \\
\hline 10 & 19 & M & Symmetric & 4.5 & 11 & 1 & $4^{\text {th }}$ & 330 & Unaffected \\
\hline 11 & 16 & $\mathrm{M}$ & Symmetric & 2.46 & 36 & 2 & $3^{\text {rd }}$ and $4^{\text {th }}$ & $288+305$ & Affected \\
\hline 12 & 11 & $\mathrm{M}$ & Symmetric & 4.75 & 36 & 1 & $4^{\text {th }}$ & 305 & Affected \\
\hline 13 & 19 & $\mathrm{M}$ & Symmetric & 2.89 & 25 & 1 & $\mathrm{R}-4^{\text {th }}, \mathrm{L}-3^{\text {rd }}$ & 305 & Unaffected \\
\hline 14 & 18 & $\mathrm{M}$ & Symmetric & 3.33 & 82 & 1 & $4^{\text {th }}$ & 330 & Affected \\
\hline 15 & 21 & $\mathrm{~F}$ & Asymmetric & 3.33 & 40 & 1 & $3^{\text {rd }}$ & 330 & Unaffected \\
\hline 16 & 31 & $\mathrm{M}$ & Asymmetric & 5.05 & 72 & 2 & $3^{\text {rd }}$ and $4^{\text {th }}$ & $305+330$ & Affected \\
\hline 17 & 25 & M & Symmetric & 4.23 & 30 & 2 & $4^{\text {th }}$ and $5^{\text {th }}$ & $355+355$ & Unaffected \\
\hline 18 & 16 & $\mathrm{M}$ & Asymmetric & 3.28 & 24 & 1 & $\mathrm{R}-5^{\text {th }}, \mathrm{L}-4^{\text {th }}$ & 288 & Affected \\
\hline 19 & 21 & $\mathrm{M}$ & Symmetric & 4.17 & 20 & 1 & $4^{\text {th }}$ & 330 & Affected \\
\hline
\end{tabular}

R: Right, L: Left

Table II. Blood flow characteristics before and after bar removal

\begin{tabular}{|c|c|c|c|c|c|c|c|c|}
\hline $\begin{array}{c}\text { PATIENT } \\
\text { NO }\end{array}$ & BEFORE BAR REMOVAL & & & & AFTER BAR REMOVAL & & & \\
\hline & wave form & & PSV & $\mathrm{S} / \mathrm{D}$ & wave form & & PSV & $\mathrm{S} / \mathrm{D}$ \\
\hline 1 & TRIPHASIC & PATENT & 97 & 5.2 & TRIPHASIC & PATENT & 101 & 5.3 \\
\hline 2 & MONOPHASIC & OBSTRUCTED & 37 & 3.1 & BIPHASIC & PATENT & 65 & 3.2 \\
\hline 3 & TRIPHASIC & PATENT & 67 & 4.1 & TRIPHASIC & PATENT & 67 & 3.7 \\
\hline 4 & BIPHASIC & PATENT & 75 & 4.8 & BIPHASIC & PATENT & 84 & 4.3 \\
\hline 5 & MONOPHASIC-DAMPENED & OBSTRUCTED & 50 & & MONOPHASIC-DAMPENED & OBSTRUCTED & 23 & \\
\hline 6 & BIPHASIC & PATENT & 80 & 3.6 & BIPHASIC & PATENT & 92 & 3.2 \\
\hline 7 & NO FLOW & OBSTRUCTED & & & BIPHASIC & PATENT & 55 & 2 \\
\hline 8 & MONOPHASIC-DAMPENED & OBSTRUCTED & 24 & & BIPHASIC & PATENT & 53 & 3.1 \\
\hline 9 & BIPHASIC & PATENT & 51 & 3.9 & BIPHASIC & PATENT & 53 & 3.9 \\
\hline 10 & BIPHASIC & PATENT & 48 & 2.9 & BIPHASIC & PATENT & 55 & 3.6 \\
\hline 11 & MONOPHASIC-DAMPENED & OBSTRUCTED & 12 & 2.2 & BIPHASIC & PATENT & 50 & 3.1 \\
\hline 12 & MONOPHASIC & ABNORMAL DISTURBED & 30 & 2.2 & BIPHASIC & PATENT & 50 & 3.1 \\
\hline 13 & BIPHASIC & PATENT & 70 & 4.1 & BIPHASIC & PATENT & 65 & 4.2 \\
\hline 14 & MONOPHASIC & ABNORMAL DISTURBED & 44 & 2.4 & BIPHASIC & PATENT & 77 & 3.2 \\
\hline 15 & NO FLOW & OBSTRUCTED & & & NO FLOW & OBSTRUCTED & & \\
\hline 16 & MONOPHASIC & ABNORMAL DISTURBED & 15 & 2.1 & BIPHASIC & PATENT & 67 & 3.9 \\
\hline 17 & BIPHASIC & PATENT & 40 & 3.6 & BIPHASIC & PATENT & 42 & 4.1 \\
\hline 18 & MONOPHASIC & ABNORMAL DISTURBED & 20 & 3.7 & BIPHASIC & PATENT & 58 & 3.8 \\
\hline 19 & MONOPHASIC & ABNORMAL DISTURBED & 59 & 1.2 & BIPHASIC & PATENT & 110 & 4.4 \\
\hline
\end{tabular}


has also been reported that erosion of the ITA due to the Nuss bar can cause delayed acute bleeding after 4 months [21]. None of our patients had this kind of complications during the bar(s) presence (11-82 months). ITA has clinical importance in CABG. Patients with Nuss procedure history should be evaluated for ITA patency before CABG.

Mechanical compression has been suggested as the main factor for ITA distortion [6, 10, 21-23]. Külcü and his colleagues have suggested that the preoperative sternal angle absorbs the highest retrosternal pressure and makes it possible to designate the lower sternal half [11]. They reported that $67 \%$ of the patients had unilateral obstruction or highly decreased flow pattern of the ITAs. In their study, despite an asymmetrical character in two of their patients, both ITAs were unaffected in PE patients. Low placement of the bar could explain this because of the decreased diameter of ITAs. ITAs bifurcate after the fifth or sixth intercostal space (ICS) and for CABG purpose ITAs are usually ligated at this point. It has also been suggested that Nuss bar placement lower than the fourth ICS should not endanger ITA usability by retaining sufficient ITA length. In our cases, the bars were placed in the $3^{\text {rd }}$ and $4^{\text {th }}$ ICS in two of the patients who had permanent obstruction.

Doppler US is a well- established noninvasive method for ITA patency evaluation [24]. To our knowledge, this study is the first to evaluate ITA patency with Doppler US in PE patients who are evaluated before and after the bar removal. In contrast to CTA, Doppler US is radiation free. Therefore, imaging of the young subjects increases the likelihood of potential use of Doppler US in patients with PE inorder to decrease radiation exposure. The only challenge during the examinations was to overcome striking chest deformities when placing the probe to trace ITAs. Doppler US could not be performed in three patients with huge deformities, who were not included in the results and this was the major limitation of our study. Secondly, CTA was not performed in these patients as it is the gold standard for ITA evaluation. Külcü and his colleagues had a similar study and performed CTA for evaluation of ITA patency after removal of the Nuss bars [11]. Our findings were not in line with their results. Their initial report was based on six patients which was a small sample size. ITA patency and future usability in CABG is still under debate and the patency of ITA after the bar removal is not concluded yet. We suggest that larger number of PE patients should be searched by using the most suitable imaging modality for the evaluation of ITA patency after the bar removal. Another limitation was that none of our patients were examined before the bar placement in terms of ITA patency by either CTA or Doppler US assuming ITAs were all patent.

In conclusion, after the bar removal, only $10 \%$ of the ITAs are totally obstructed unilaterally. Color Doppler US is a safe method to evaluate ITA patency in clinical settings which allows repeated measurements without the risk of radiation exposure. Long term consequences has to be followed with larger patient groups in different time intervals.

\section{References}

1. Kelly RE Jr. Pectus excavatum: historical background, clinical picture, preoperative evaluation and criteria for operation. Semin Pediatr Surg 2008;17:181-93. doi: 10.1053/j.sempedsurg.2008.03.002.

2. Bostanci K, Ozalper H, Yuksel M. Minimally invasive repair technique for pectus excavatum deformity. Marmara Med J 2011;24:38-43. doi: 10.5472/MMJ.2010.01752.1

3. Brochhausen C, Turial S, Müller FK, et al. Pectus excavatum: history, hypotheses and treatment options. Interact Cardiovasc Thorac Surg 2012;14:801-6. doi: 10.1093/icvts/ivs045.

4. Kelly RE Jr, Lawson ML, Paidas CN, Hruban RH. Pectus excavatum in a 112-year autopsy series: anatomic findings and the effect on survival. J Pediatr Surg 2005;40:1275-8. doi: 10.1016/j.jpedsurg.2005.05.010.

5. Ravitch MM. The operative treatment of pectus excavatum. Ann Surg 1949;129:429-44.

6. Kelly RE, Goretsky MJ, Obermeyer R, et al. Twenty-one years of experience with minimally invasive repair of pectus excavatum by the Nuss procedure in 1215 patients. Ann Surg 2010; 252:1072-81. doi: 10.1097/SLA.0b013e3181effdce.

7. Kuru P, Bostanci K, Ermerak NO, Bahadir AT, Afacan C, Yuksel M. Quality of life improves after minimally invasive repair of pectus excavatum. Asian Cardiovasc Thorac Ann 2015;23:302-7. doi: 10.1177/0218492314553442.

8. Nuss D, Kelly RE Jr, Croitoru DP, Katz ME. A 10-year review of a minimally invasive technique for the correction of pectus excavatum. J Pediatr Surg 1998;33:545-52.

9. Moore KL. The internal thoracic artery. In: Gardner $\mathrm{JN}$, editor. Clinically Oriented Anatomy. 2nd edition. Baltimore:Williams and Wilkins, 1985:75.

10. Yüksel M, Özalper MH, Bostanci K, et al. Do Nuss bars compromise the blood flow of the internal mammary arteries? Interact Cardiovasc Thorac Surg 2013;17:571-5. doi: 10.1093/icvts/ivt255.

11. Külcü K, Elenbaas TW, Nguyen DT, et al. Patency of the internal mammary arteries after removal of the Nuss bar: an initial report. Interact Cardiovasc Thorac Surg 2014;19:6-9. doi: 10.1093/icvts/ivu083.

12. Umurolu T, Bostancı K, Thomas DT, Yüksel M, Göğüs FY. Perioperative anesthetic and surgical complications of the 
Nuss procedure. J Cardiothorac Vasc Anesth 2013;27:43640. doi: 10.1053/j.jvca.2012.10.016.

13. Yüksel M, Bostanc1 K, Evman S. Minimally invasive repair after inefficient open surgery for pectus excavatum. Eur J Cardiothorac Surg 2011;40:625-9. doi: 10.1016/j. ejcts.2010.12.048.

14. Kuru P, Dudakli A, Mursaloglu H, Arikan H, Oktay A, Yuksel M. How pulmonary function changes after pectus excavatum correction surgery. Asian Cardiovasc Thorac Ann 2015;23:945-9. doi: 10.1177/0218492315596464.

15. Park HJ, Jeong JY, Jo WM, et al. Minimally invasive repair of pectus excavatum: a novel morphology-tailored, patientspecific approach. J Thorac Cardiovasc Surg 2010;139:37986. doi: 10.1016/j.jtcvs.2009.09.003.

16. Park HJ, Lee SY, Lee CS. Complications associated with the Nuss procedure: analysis of risk factors and suggested measures for prevention of complications. J Pediatr Surg 2004;39:391-5.

17. Hosie S, Sitkiewicz T, Petersen C, et al. Minimally invasive repair of pectus excavatum - the Nuss procedure. A European multicentre experience. Eur J Pediatr Surg 2002;12:235-8. doi: 10.1055/s-2002-34486.

18. Hebra A, Swoveland B, Egbert M, et al. Outcome analysis of minimally invasive repair of pectus excavatum: review of
251 cases. J Pediatr Surg 2000;35:252-8.

19. Fallon SC, Slater BJ, Nuchtern JG, et al. Complications related to the Nuss procedure: minimizing risk with operative technique. J Pediatr Surg 2013;48:1044-48. doi: 10.1016/j. jpedsurg.2013.02.025.

20. Nasr A, Fecteau A, Wales PW. Comparison of the Nuss and the Ravitch procedure for pectus excavatum repair: a metaanalysis. J Pediatr Surg 2010;45:880-6. doi: 10.1016/j. jpedsurg.2010.02.012.

21. Adam LA, Meehan JJ. Erosion of the Nuss bar into the internal mammary artery 4 months after minimally invasive repair of pectus excavatum. J Pediatr Surg 2008;43:394-7. doi: 10.1016/j.jpedsurg.2007.10.002.

22. Haller JA, Kramer SS, Lietman A. Use of CT scans in selection of patients for pectus excavatum surgery: a preliminary report. J Pediatr Surg 1987;22:904-6.

23. Liu W, Kong D, Yu F, Yin B. A simple technique for pectus bar removal using a modified Nuss procedure. J Pediatr Surg 2012;48:1137-41. doi:10.1016/j.jpedsurg.2013.01.052.

24. Meyer GP, Laudenberg B, Hausmann D, et al. Transthoracic Doppler validation in mammary artery grafts after minimal invasive direct coronary artery bypass operation. J Am Soc Echocardiogr 2004;17: 954-61. doi: 10.1016/j. echo.2004.05.013. 